NEW LITERARIA-

An International Journal of Interdisciplinary Studies in Humanities

Volume 3, No. 1, January-February, 2022, PP. 134-140

ISSN: 2582-7375

DOI: https://dx.doi.org/10.48189/nl.2022.v03i1.015

www.newliteraria.com

\title{
Magical Immunization: Occult and the Pandemic in Nora Roberts' Year One
}

\section{Isha Biswas}

\begin{abstract}
With the world in topsy-turvy strained under the tides of a pandemic that shows no sign of ebbing, there has been a massive surge in consumption- no pun intended- of supernatural fiction and fantasy literature. Either as a means of escape from reality, or as a deep-dive into an allegorized society in crisis (or a world directly and terrifyingly reflective of the 2020s), fantasy with a dystopian, apocalyptic setting has always found a large readership. Concomitantly, there has been a re-popularization of the occult in real life as well: and this paper shall investigate Nora Roberts' Year One keeping that in mind in the context of the author's creation of the supernaturally-aided and supernaturally-quelled pandemic in her novel. Alarmingly predictive of the Covid-19 horror, Roberts' narrative follows the life of the survivors of a disastrous, selfmutative airborne virus that levels more than half of the world population in weeks. I shall investigate socio-literary implications of how most of the unaffected are revealed to possess magical abilities which are shown to be genetically and generationally coded, thus causing a divide between them and the non-magical victims, culminating into a eugenicist drive of culling which turns into an actual "witch"-hunt. Taking into account the cultural connotations of choosing Scotland as Roberts' preferred setting for the genesis of the plague coupled with her use of Scottish legends about dark forces, the paper will further delve into possible evocation of Celtic pagan mythologies, occult medical lore, and the inspiration drawn from the accusation and persecution of marginalized "white witch"/ "witch doctor"/ "wise women" healers during Black Death and witch trials in early modern Scotland.
\end{abstract}

Keywords: Magic, Witch Hunt, Celtic, Plague Literature, Fantasy, Healers, Selectivity.

\section{Introduction: Revere 'Pureblood/Mudlood' Darwinism}

Supernatural fiction and fantasy genre have now perhaps, in light of recent events, become less of an escapist castle in the sky and more of a reflection or revealing and demonstrative of contemporary life. A sign of the times, the doomsday narrative of Nora Roberts' novel follows the life of the survivors of a disastrous, self-mutative airborne virus that levels more than half of the world population in weeks. Although ground zero of the spread of infection remains unknown to the protagonists through most of their journey for plot purposes, suspicions regarding possible unnatural causes keep accumulating based on key evidence: the ferocity of symptoms in hitherto healthy bodies, speed of infection, high mortality rate, and a nearly negligible incubation period. With unknowable, untamable, irreversible disasters, comes the tendency to find supernatural grounds remotely worthy of scapegoating, which is reminiscent of the sociological response to outbreaks of Black Plague in early modern Europe.

Historian Louise Marshall (2008) points out: "Epidemics were usually understood as 
having been let loose upon the world by supernatural forces: one or many gods, demons, or spirits of the dead." (Marshall, 2008, p. 594) It is undeniable, that epidemics produce widespread societal unrest and elicit responses aimed at determining the root causes of illness outbreaks. To rationalize and explain the origins and progress of occurrence and recurrence of diseases yet unidentified and strange, civilizations have manufactured scapegoats by condemning otherwise innocent people throughout history: "Patterns of scapegoating often mirror existing social prejudices, as the socially disempowered become objects of blame. Religious, ethnic, political, economic, and sexual prejudices all factor into the process of scapegoating, and these affiliations are not mutually exclusive" (Marshall, 2008, p. 594).

Planning her narrative as an exception to what Marshall had postulated, Nora Roberts makes it clear that it is not the supernaturalization of at-risk communities that led to their persecution in her story, but its reversal. The existence of magical beings cohabiting Earth with humans becomes vulnerable to the wrath of the non-magical, fearfully religious communities, once they begin detecting their presence and correlating them wrongly to the spread of the otherwise inexplicable biomedical Armageddon. Most of the insusceptible discover themselves manifesting (previously hidden or otherwise) occultic immunocompetence which is shown to be genetically and generationally coded, thus causing a divide between them and the nonmagical victims, culminating into a eugenicist drive of culling which turns into an actual "witch"-hunt.

The novel keeps pace through a ravaged, post-apocalyptic metropolitan wasteland, where instead of mindless zombies, the protagonists- both superpowered and human- face something perhaps more sinister: scavenging mercenaries, profiteering organizations, and military camp imprisonment of the immune for genetic experimentation. Coupled with such state-sponsored persecution, religious zealots bandied together and were out for blood: what follow are events inspired from documentation of the Church and the secular government's role in transatlantic witch-hunts across Europe and America till the $17^{\text {th }}$ century. In Roberts' novel, we meet similar extremist, evangelical group who called themselves the Purity Warriors, who would use the residual internet facilities to their advantage by spamming servers with provocative/incendiary messages which focus on very specific keywords that might incense the already fearful public against the suspected supernatural:

'Attention all God-fearing humans: if you are reading this, you are one of the chosen. No doubt you have lost those dear to you and have felt, may still know, despair. No doubt you have witnessed firsthand the abominations that have desecrated the world Our Lord created. You may believe the End Times are upon us. But take heart! You are not alone! Have Faith! Have Courage! We who survived this demonic plague wrought by Satan's Children face A Great Test! Only we can defend our world, our lives, our very souls. Arm yourselves and join The Holy Crusade. Will you stand by while our women are raped, our children mutilated, while the very survival of humanity is threatened by the ungodly [...] The future of the Human Race is in our hands. To save it we must soak them in the blood of the demon. Gather together, Chosen Warriors! Hunt, Kill, Destroy the EVIL that threatens us. "Thou shalt not suffer a witch to live," so sayeth The Lord. This is the time of retribution! This is the time of The Slaughter! This is the time of The Purity Warriors! I am with you. I am of you. I am filled with the light of righteous vengeance.' Reverend and Commander Jeremiah White. (Roberts, 2017, p. 374, emphasis mine)

This is reminiscent of the Church's creation of an imagined enemy (Harris, 1974, p. 237) in conjuring the idea of an underground anti-Christian network of demonic sorcery and witchcraft (as opposed to Christian miracles and thaumaturgy), to buttress public adherence to itself. One may consider the author's diegetic tactic as a spin on the Voldemortian pureblood/mudblood separatism: the supernaturally evolved beings are now considered impure in Year One, and prone to persecution by the human species. Needless to say, this is patently 
closer to historical reality. Often, those same diabolized networks which were degraded as heathen and heretic, were actually pagan, pre-Christian Old World cultures (Ball, 2018, p. 2).

\section{Ground Zero: Celtic Scotland}

This brings us to the next area of interest, Roberts's employment of Scottish legends and mythologies in prefiguring an alternative dimension of theological lore behind both the origin of the neo-plague, and the end of it. The first carrier and casualty, or Patient Zero: Ross MacLeod, experiences the paranormal contagion at night in a secluded Celtic stone circle in Dumfries, Scotland. Celtic tales speak of a cross-culturally known magical creature in this respect: fairies.

The fairies send diseases to punish those who offend against their space and time taboos (i.e., people who go out into the open at night or noon or during the feasts of the dead or approach their springs, paths or dancing spots or trace the steps of their ring dances). (Pocs, 2017, p.258)

This is the sacred space that Macleod infringed upon and also polluted by harming the protected wildlife of the region, thereby warping and unsealing dark forces beyond containment. That wasn't even the first time he commits the encroachment, as evinced by his childhood capers with his playmates:

Often, on dark nights, they'd crept out of the house to hike to the very field they walked now, to hold secret meetings and try to raise the spirits within the little stone circle the locals called sgiath de solas, shield of light. They'd never succeeded, nor had they ever chased down the haints or faeries young boys knew traveled the forests. (Roberts, 2017, p. 9)

Faeries, shapeshifters and diviners in the novel are shown to be some of the strongest magical creatures, with varied powers. Two of the tritagonists who escape from diseaseravaged hometowns and help rebuild and protect the community of survivors, are Fred and Starr, both possessing powers of flight, unlocking doors (Roberts, 2017, p. 106), transfiguration, telepathy (Roberts, 2017, p. 329), casting spells and creating charms for defense (Roberts, 2017, p. 291). It's noteworthy that each of these attributes recorded in Celtic fairytales had also coincided with or rather were assimilated into witchcraft and demonological discourse of $16^{\text {th }}$ and $17^{\text {th }}$ century Scotland. Canon J. A. MacCulloch (1921) argues:

Official, ecclesiastical orthodoxy of Europe had long regarded all spirits as either angelic or demoniac. Fairies, elves, brownies, water-sprites, forest and woodland folk, were certainly not angels; therefore they must be demons. In all the writings of the mediaeval period they are demons [...] Fairy-land and its denizens had become a real part of Satan's kingdom of darkness. It was therefore inevitable that in course of time, and especially after the witchcraft prosecutions began in the fourteenth century, the folk themselves should more or less accept a view of their own creations which was imposed upon them by their spiritual pastors and masters. They did not accept it wholly, but in so far as they did, and in so far as the common aspects of the beliefs in fairies and witchcraft also aided, the common ban under which both were placed would inevitably tend to mix both together in their minds. The theological view of both matters was quite clear and straightforward, and both fairies and the mediaeval and post-Reformation witches were regarded as of Satan's train. At all events, the evidence from three sources is clear enough regarding it. These are: (I) certain poems of the Reformation period; (2) the copious evidence of several witch-trials; (3) King James VI' s book on Daemonologie (I598). (MacCulloc, 1921, pp. 231-243)

Additionally, Roberts makes use of the motif of crows throughout her story as a potent harbinger of doom: which is evocative of mythical personifications of the avian creature that supposedly brought "war, death, and foreboding" (Monaghan, 2004, p. 106). The symbol is covertly introduced in the first chapter that revolves around Ross Macleod: 
On one midnight adventure, when even the air held its breath, Ross swore he'd felt a dark presence, heard its rustling wings, even smelled its foul breath. Felt- he would always claim- that breath blow into him. In adolescent panic, he'd stumbled in his rush to flee the circle, and scraped the heel of his hand on a stone within. A single drop of his blood struck the ground. (Roberts, 2017, p. 9)

Crows and related avian creatures like ravens have been symbolic of war and death in Celtic mythology. In Year One, the ancient magic that takes the form of a plague springs from the blood of crows shed unnecessarily and cruelly by Ross and his friends. The blood-soaked initiation of the story becomes an omen of similar devastation that shall wreck mankind in the following weeks. Later in the novel, the same motif of crows and carrion birds of prey being agents of destruction shall be revisited in the figures of antagonistic sorcerers who have turned to the dark side- Eric and Allegra- with their wings they gained from the worship of spirits similar to what caused the pandemic (Roberts, 2017, p. 282).

\section{Neo-Pagan Libertor: Refashioning Gaelic Celts}

What makes the occult origin more fascinating is the parallel strain of hope of regeneration that is foretold by a Scottish fairy soothsayer who simultaneously warns of the impending global disaster: "So now the end and the grief, the strife and the fear- the beginning and the light. I ne'er thought to live for it" (Roberts, 2017, p. 14). Ross McLeod, patient zero, or the "firstfooter" as the old 'fae' oracle calls him, would be the first to fall prey to it on account of his own blood and that of his kill, spilled on holy ground: an act of defilement that had fortified evil paranormal forces. The same shall infect anyone close to him, forming a centrifuge of infection that spreads globally, for humankind to be purified and rebuilt by a messianic saviour from the future generation. Although the narrative does seem very Biblical, the author employs previously unused motifs from belief system of the Gaelic Scot and Irish- whose faith was termed "barbaric" (Foster, 2016, p. 2) and extensively persecuted by Christianity which it had predated by centuries. Herein lies a revival of Celtic lore into a judgement-day-esque prophecy and a heroification of the concept of pagan supernatural magic-wielders who were beyond the control of the Church, and who had otherwise been historically demonized. The Scottish oracle speaks to truth a bleak future and humanity's salvation in no uncertain words, and references a major mythic pantheon:

The shield will be broken, the fabric torn, by the blood of the Tuatha de Danaan [...] So now between the birth and the death of time, power rises - both the dark and the light-from the long slumber. Now begins the blood-soaked battle between them. And with the lightning and a mother's birth pangs comes The One who wields the sword. The graves are many, with yours the first. The war is long, with no ending writ. (Roberts, 2017, p. 15)

The description does evoke images from religious iconography of Mary and the birth and prophesied rapture of Christ, but subverts it in two ways: the redeemer to be born is a woman who would go on to complete her journey to power and destiny in the rest of the series, and secondly it directly ties in to the agrarian Celtic paganism and Iron Age polytheism (Ritari \& Bergholm, 2015, p. 3) and their deification of the primordial power symbolized by motherhood, connected with nature and her formidable forces, both idealized and idolized in the figure of the Divine Feminine.

\section{De Diva Terre: Goddess of the Earth}

Roberts' novel alludes to Danu (alternatively known as Dana or Anu), who is hailed as the female principle ("Danu: Celtic Goddess", 2017, n.p.) and the ancient Celtic counterpart to other proto-Indo-European earth-mother deities in matrifocal, polytheistic cultures (MacLeod, 1998, p. 349). The "divine race" associated with Danu were termed the Tuatha De Danaan, the 
same supernaturally capable people that the oracle hails as the ones who would save humankind in this war:

They were later called the Dana O'Shee or fairy folk, after being demoted and diminished from divinity into folktale figures [...] [After the war with invading Milesians] The ancient race remained within the hills, under the bogs, and in other luminal areas, where they were transformed into the fairy people. Sometimes the story of their fall from power was connected to the Christian story of the angels' fall from heaven, and the fairies were thus described as fallen angels. (Monaghan, 2004, p. 117, 168)

They were subsequently decried as demons and false gods, their worship declared heretic and idolatrous. Choosing Danu and Her militant progeny is instrumental in creating a non-Christian mythopoeic deliverance of humankind, given their preternatural origin and mutant, metahuman existence who stand as guardians of the world against a paranormal plague. I would further argue a deeper root of the magical warrior race in ancient land-and-war-goddess mythoi as well. Danu, or Anu, finds her incarnation in Old Irish mythologies as Mor-Rioghain or the Morrigan:

[She] emerges in the tradition as the goddess of war par excellence, and this primary role has coloured her portrayal in the literature, where she appears hostile to the personages whose deaths she is foreboding. That she is, however, an emanation from the earth-goddess (representing her war-function), is evident from her intimate association with the landscape and fertility. (Lysaght, 1996, p.161)

\section{Matrifocality and the Wise Women/ White Witch}

The associations of the dualistic mother-warrior goddess cults and earth/land fecundity bring the motifs full circle to the fairy oracle's predictive imagery of the mother's labour pain and saviour's impending birth. The saviour is supposed to restore harmony to the fallen civilization as well as revitalize the untended, desolate megalopolis badlands of a post-apocalyptic biosphere. The paradoxical but very maternal themes of healing and resistance, creation and combat run through the actions of Lana Fallon, the first progenitor of the new-age Tuatha de Danaan generation. Conventionally her role could be of a benevolent or "white witch" (Levack, 2014, p.2): a term used derisively nonetheless per early modern demonological discourse, wherein those accused of white witchcraft or munificent magic were still feared as dangerous as their malevolent counterpart. Lana is shown to psychokinetically deploy massive forcefields that physically moves vehicles aside (Roberts, 2017, p.70) to clear their path to evacuation, embodying characteristics adjacent to imagined instances of magic-users and their abilities of elemental and matter manipulation (Henderson, 2016, p.59).

She uses the same willpower to reverse damages incurred by a survivor with gunshot injury, 'dressing' the wound without any external medical help. The mother of the messiah being a healer is very telling:

She didn't know what stirred in her, but it reached up and out, it quivered to help. She kept one hand gripping [the victim's], the other pressed on the exit wound. Let it flow

out. It hurt. She heard the pain, felt it, saw it black and pulsing. She opened herself to whatever rose and stirred and flowed-white and cool against the black and hot. (Roberts, 2017, p. 172)

This is of course a more fantastical representation of how the archetypal Wise Women would work skilfully to alleviate illnesses. "[Historically marginalized, the Wise Women/Cunning Women were] repositories of autodidactic yet advanced herbal knowledge, thus inspiring the distaste and disbelief of those who were trained in the ways of Malleus Maleficarum which scoffed at the probabilities of women possessing legitimate medical skills" (Biswas, 2021, p. 253). Malleus Maleficarum, or The Hammer of the Witch, 1487, was Heinrich 
Kramer and Jacob Sprenger's anti-witchcraft tract which had partly consolidated public hysteria and Church-sanctioned and State-ordained legalized violence against the nonnormative in transcontinental trials. Scottish witch hunts focussed on wiping out anybody suspected to be remotely connected to non-Christian supernatural devices, and specifically scapegoated self-taught female apothecaries and healers by labelling them with the 'scarlet letter' of "witch":

Witches are chiefly employed in plain mischief by hurting persons or their goods. But they sometimes work mischief under a pretence or colour of doing good; as when they cure diseases, loose enchantments and discover other witches. All their designs are brought about by charmes or ceremonious rites instituted by the Devil. (Forbes, 1730, p. 32)

History seems to repeat itself in Year One, with similar rabid witch-hunts beginning to spread like wildfire amid mass deaths of the those who are not supernaturally enhanced or genetically equipped to deal with the infection. Starr, the young teenaged fairy loses her mother to raiders who rape and brutalize her when she distracts them away from her daughter to help her escape. The narrative's Harry Potter-esque quality of characterizing mothers as protective/sacrificial is part of a longstanding tradition of magical maternity that stemmed from patriarchal glorification of pregnancy/motherhood. This had further led to a dehumanization and demonization of female sexuality and creative potential in Western media (Francus, 1994). However, Roberts' story does envisage a homage to the post-1980s fantasy depictions of feminist empowerment found at the subversive politico-sexual fulcrum balanced between "witches' maternal values... [and] their transgressive potential" (Engelbrecht, 2021, p. 2)

\section{Conclusion}

Roberts has constructed a story that revisits aspects of the ancient culture of the Gaels and Celts and provides the space to question its demonization and oppression by the church in the same strain as one would criticize the marginalization of other traditions and belief systems of OldWorld religions. Along with it, she ushers in a genre-blended form of plague literature: from stories like Dan Brown's Inferno where man-made bio-weaponized pandemic that killed via 'randomization', undeterred by magic or technology (Biswas, 2020, p. 3), we now move into more occultized territories of speculative science fantasy. Nora Roberts has sparked a sub-trend in the genre of speculative fiction, and this is the only the beginning of an ethics discourse regarding the genealogical totipotence of the supernatural in a demodystopian scenario.

\section{Reference}

Ball, C. (2018). Wicca, Witchcraft and the Goddess Revival: An Examination of the Growth of Wicca in Postwar America, in Beavis, M.A. \& Hwang, H.H-S., M. (eds.) Goddesses in Myth, History and Culture, Lytle Creek, CA: Mago Books.

Biswas, I. (2020). Can "Disease" be the Cure?: Bio-Weapons in Population Control, Demodystopia, and the Question of Consent in Dan Brown's Inferno. The Golden Line: A Magazine of English Literature, 3(1). http://goldenline.bhattercollege.ac.in/v3n121/

Biswas, I. (2021). Cry Witch: Representation of German Witch-Lore and Persecution of Dispossessed Women in Oliver Potzsch's The Hangman's Daughter and Erika Mailman's The Witch's Trinity. Dibrugarh University Journal of English Studies, 29 (2020-21), 250-261. https://www.dujes.co.in/p/cry-witch-representation-ofgerman.html

Britannica, T. Editors of Encyclopaedia. (2017, May 30). Danu. Encyclopedia Britannica.

Canon J. A. MacCulloch. (1921). The Mingling of Fairy and Witch Beliefs in Sixteenth and Seventeenth 
http://www.jstor.org/stable/1255201

Engelbrecht, J. (2021). Magical Mothers: The Representation of Witches and Motherhood in Contemporary Fantasy Cinema. Communicatio, 47(1), 20-41. https://doi.org/10.1080/02500167.2021.1876122

Forbes, W. (1730). The Institutes of the Law of Scotland. By William Forbes. United Kingdom: J. Watson.

Foster, E. M. (2016). The Irish theology: Formation of Celtic Christianity in Ireland (5th to 9th century). CORE. Retrieved November 17, 2021, from https://core.ac.uk/reader/228820487.

Francus, M. (1994). The Monstrous Mother: Reproductive Anxiety in Swift and Pope. ELH, 61(4), 829-851. http://www.jstor.org/stable/2873360

Harris, M. (1974). Cows, Pigs, Wars, and Witches: The Riddle of Culture. Random House.

Henderson, L. (2020). Witchcraft and Folk Belief in the Age of Enlightenment: Scotland, 16701740 (Palgrave Historical Studies in Witchcraft and Magic) (1st ed. 2016 ed.). Palgrave Macmillan.

Levack, B. P. (2014). The Oxford Handbook of Witchcraft in Early Modern Europe and Colonial America. Oxford University Press.

Lysaght, P. (1996). Aspects of the Earth-goddess in the Traditions of the Banshee in Ireland. In S. Billington \& M. J. Aldhouse-Green (Eds.), The Concept of the Goddess (pp. 152165). Routledge.

MacLeod, S. P. (1998). Mater Deorum Hibernensium: Identity and Cross-Correlation in Early Irish Mythology. Proceedings of the Harvard Celtic Colloquium, 18/19, 340-384. http://www.jstor.org/stable/20557350

Marshall, L. (2008). Religion and Epidemic Disease. In J. P. Byrne (Ed.), Encyclopedia of Pestilence, Pandemics, and Plagues. Volume 1, A-M. Greenwood Press.

Monaghan, P. (2004). The Encyclopedia of Celtic Mythology and Folklore. New York: Facts On File.

Pocs, E. (2017). Small Gods, Small Demons: Remnants of an Archaic Fairy Cult in Central and South- Eastern Europe. In M. Ostling (Ed.), Fairies, Demons, and Nature Spirits: "Small Gods" at the Margins of Christendom (Palgrave Historical Studies in Witchcraft and Magic) (pp. 255-276). Palgrave Macmillan.

Ritari, K., \& Bergholm, A. (2015). Understanding Celtic religion: Revisiting the pagan past. University of Wales Press.

\section{Bio-note}

Ms. Isha Biswas is a PhD scholar in the Department of English, Vidyasagar University. She is also a lecturer in PCM college, West Bengal, India.

Email Id: yoshinokurosaki@gmail.com 